\title{
Changes in dietary habits, physical activity and status of metabolic syndrome among expatriates in Saudi Arabia
}

Rasmieh A. Alzeidan ', Fatemeh Rabiee ${ }^{2}$, Ahmed A. Mandil ${ }^{3}$, Ahmad S. Hersi ${ }^{7}$ and Anhar A. Ullah ${ }^{1}$

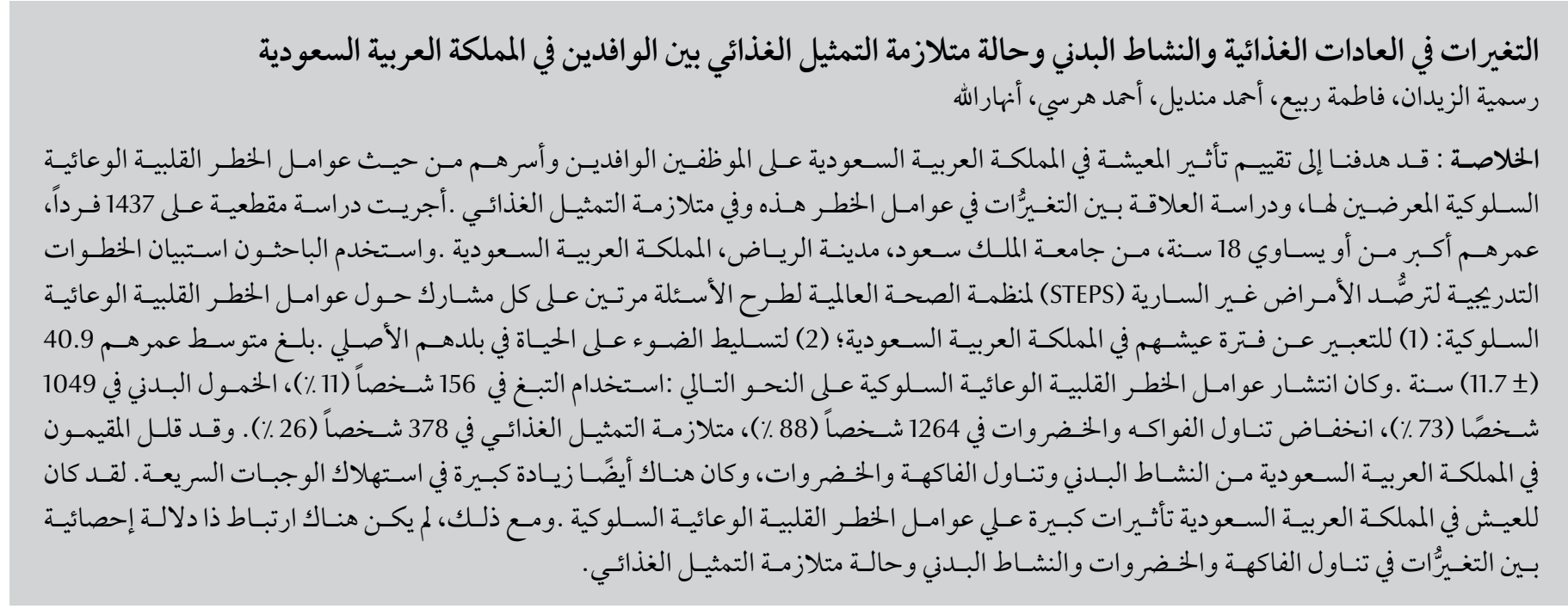

ABSTRACT The aim of this paper is to assess the impact of living in Saudi Arabia on expatriate employees and their families' behavioural cardiovascular risk factors (BCVRFs), and to examine the association between changes in BCVRFs and metabolic syndrome (MetS). A cross-sectional study was conducted on 1437 individuals, aged $\geq 18$ years, from King Saud University in Riyadh, Saudi Arabia. We used the World Health Organization STEPS questionnaire to ask every participant questions about BCVRFs twice: (1) to reflect their period of living in Saudi Arabia and (2) to shed light upon life in their country of origin. Their mean age was 40.9 (11.7) years. The prevalence of BCVRFs was as follows: tobacco use in 156 (11\%), physical inactivity in 1049 (73\%) low intake of fruit and vegetables in 1264 (88\%) and MetS in 378 (26\%). Residing in Saudi Arabia had reduced physical activity and intake of fruit and vegetables. There was also a significant increase in the fast food consumption. In conclusion, living in Saudi Arabia had a significant negative effect on BCVRFs. However, there was no statistically significant association between changes in fruit and vegetable intake and physical activity and MetS status, except that intake of fast food was lower among participants with MetS.

\section{Changements concernant les habitudes alimentaires et l'activité physique, et situation du syndrome métabolique parmi les expatriés vivant en Arabie saoudite}

La présente étude avait pour objectif d'évaluer l'impact de la vie en Arabie saoudite sur les employés expatriés, ainsi que les facteurs de risque cardio-vasculaire comportementaux de leurs familles, et d'examiner l'association entre les changements en termes de facteurs de risque de ce type et le syndrome métabolique. Une étude transversale a été menée auprès de 1437 individus âgés de 18 ans et plus à l'Université Roi Saoud de Riyad, en Arabie saoudite. Nous avons utilisé le questionnaire STEPS de I'Organisation mondiale de la Santé afin d'interroger chaque participant à deux reprises au sujet des facteurs de risque cardio-vasculaire comportementaux afin de refléter leurs comportements durant leur séjour en Arabie saoudite et d'apporter un éclairage sur leur habitudes de vie dans leur pays d'origine. L'âge moyen était 40,9 ans (ET 11,7). La prévalence des facteurs de risque cardio-vasculaire comportementaux était la suivante : tabagisme pour 156 individus (11\%), sédentarité pour 1049 (73\%), faible consommation de fruits et légumes pour 1264 d'entre eux (88 \%) et présence de syndrome métabolique chez 378 des participants (26\%). Le fait de résider en Arabie saoudite avait réduit l'activité physique et la consommation de fruits et légumes. On observait également une augmentation significative de la consommation de fast food. Le fait de vivre en Arabie saoudite avait un impact négatif significatif sur les facteurs de risque cardio-vasculaire comportementaux. Néanmoins, il n'y avait pas d'association statistiquement significative entre les changements dans la consommation de fruits et légumes, l'activité physique et le syndrome métabolique, excepté que la consommation de fruits et légumes était plus faible chez les participants porteurs de syndrome métabolique.

'Cardiac Sciences Department, College of Medicine, King Saud University, Riyadh, Saudi Arabia (Correspondence to: R.A. Alzeidan: ras_zeidan@hotmail. com). ${ }^{2}$ School of Health Sciences, Faculty of Health, Education and Life Sciences, Birmingham City University, Birmingham, United Kingdom. ${ }^{3}$ Department of Epidemiology, High Institute of Public Health, Alexandria University, Alexandria, Egypt; WHO Regional Office for the Eastern Mediterranean, Cairo, Egypt. Received: 15/11/16; accepted: 11/12/17 


\section{Introduction}

The Gulf Cooperation Council (GCC) countries, which came into existence in 1981, include Bahrain, Saudi Arabia, Kuwait, Oman, Qatar and the United Arab Emirates (1). Following oil discovery in the Gulf region during the 1950s, these countries including Saudi Arabia lacked human resources, particularly in health professions. They have therefore attracted professionals from all over the world seeking opportunities for employment and a better standard of living (2). For this reason, the Saudi Arabian population profile has changed and, like other GCC countries, enjoys a wide variety of expatriates from diverse ethnic backgrounds.

The Annual Statistical Report from the Saudi Ministry of Health indicates that $33 \%$ of the total inhabitants (30 $770375)$ in 2014 were expatriates. In Riyadh, where the present study took place, the expatriates represented 38\% of the total population (3). Also, an official statistical report form King Saud University (KSU) showed that expatriates constituted $23 \%$ of the total university employees ${ }^{1}$.

The policies of most host countries, including the GCC, require all expatriates to undergo medical screening, and people who have health issues are usually denied entry (4). Overall, new expatriates have good health status, however, it is perceived that the health of expatriates progressively deteriorates with their duration of stay in a new host country. Such deterioration may be attributed to cultural differences, psychosocial and socioeconomic changes, as well as lifestyle changes (including dietary habits and physical activity) with migration, which may have negative impacts on health (5).

Kingdom of Saudi Arabia Statistical Report received via email (dfpa_es@ ksu.edu.sa). Accessed May 2015.
Worldwide, 6\% (3.2 million) of deaths each year are attributed to physical inactivity, where physical inactivity is considered to be the fourth most frequent cause of adult death (6). In wealthy GCC countries, particularly in Saudi Arabia, rapid socioeconomic transition and vast urbanization haveled to a predominantly sedentary lifestyle among the population. Consequently, physical inactivity has become a major public health concern in this region as well as in some other countries. Prevalence of physical inactivity varies among the countries of the Eastern Mediterranean, with the highest level in Saudi Arabia (96\%) and the lowest in the Syrian Arab Republic (31\%) (7).

Globally, $2.8 \%$ ( 1.7 million) of deaths are attributable to low consumption of fruit and vegetables (8). However, the worldwide consumption of fruit and vegetables is still below the recommended intake of $\geq 5$ five servings per day (9). Likewise, in Saudi Arabia, a recent report shows that only $3 \%$ of the population consumed the recommended daily portions of fruit and vegetables (10).

Substantial evidence worldwide demonstrates the phenomenon of acculturation, which has been simply defined as the gradual adoption of the host country's cultural patterns, including attitudes, values, customs, beliefs and behaviours by the migrants $(11,12)$. Furthermore, one of the wellestablished migration effects is dietary acculturation, where the minority groups adopt the dietary practice of their host countries (12). In addition, acculturation influences the physical activity of migrants (13).

The present study estimated the prevalence of behavioural cardiovascular risk factors (BCVRFs), including unhealthy diet and physical inactivity, among expatriate employees and their families at KSU, to assess the possible impact of living in Saudi Arabia on expatriates' BCVRFs, and the association between the changes in BCVRFs and metabolic syndrome (MetS).

\section{Methods}

\section{Study design}

This was a cross-sectional study conducted on KSU employees and their families over 9 months from 8 July, 2013 to 30 April, 2014. The current investigation was a substudy of a larger study ( $n=4500$ subjects) and focused only on non-Saudi employees and their families $(n=1437)$. The details of the larger study and participants' recruitment procedure are described elsewhere (14).

We used a modified version of the World Health Organization (WHO) STEPS questionnaire (15), version 2.1 (both Arabic and English forms). This questionnaire uses sequential steps, starting with a questionnaire (Step I), followed by physical measurements (Step II) and biochemical measurements (Step III).

All participants personally reported their sociodemographic information, such as age, sex, country of origin, marital status, educational level, job title, and length of residence in Saudi Arabia. Body weight and height and waist and hip circumferences were measured for all participants, as described previously (14). Questions about lifestyle behaviour, including diet, physical activity and tobacco use, were asked twice: (1) to describe their current behaviour and (2) to report their behavioural habits before moving to Saudi Arabia. The biochemical measurements in this study included: glycosylated haemoglobin ( $\mathrm{HbAlC}$ ), high-density lipoprotein-cholesterol (HDL-C), low-density lipoproteincholesterol (LDL-C), total cholesterol (TC) and triglyceride (TG). Participants were instructed to fast for $\geq$ 12 hours before they were subjected to blood testing. 


\section{MetS}

Using the National Cholesterol Education Programme classification $(16,17)$, participants were identified as having MetS if they had $\geq 3$ of the following 5 factors: (1) abdominal obesity measured by waist circumference; participants were considered to have abdominal obesity if waist circumference was $\geq 102 \mathrm{~cm}$ for men and $\geq 88 \mathrm{~cm}$ for women; (2) raised triglyceride $\geq 1.7 \mathrm{mmol} / 1$; (3) reduced $\mathrm{HDL}, \leq 1.03 \mathrm{mmol} / \mathrm{l}$ for men and $\leq 1.29 \mathrm{mmol} / \mathrm{l}$ for women; (4) raised fasting plasma glucose $(\geq 5.6$ $\mathrm{mmol} / \mathrm{l}$ ) or under treatment for and/ or previously diagnosed with diabetes; and (5) hypertension (systolic blood pressure $\geq 130 \mathrm{mmHg}$ and/or diastolic blood pressure $\geq 85 \mathrm{mmHg}$ or under treatment for hypertension).

\section{Statistical analysis}

Categorical data were summarized as absolute numbers and percentages. Numerical data were summarized with means and standard deviations (SDs). Categorical variables were compared using the $\chi^{2}$ testor Fisher's exact test, and continuous variables were compared using independent sample $t$ test or Mann-Whitney $U$ test. To compare the dietary habits and physical activity patterns of participants before and after residingin SaudiArabia, we used a paired sample t test. To study the association of duration of stay, gender and MetS with changes of dietary habits and physical activity patterns, a calculation was done using the mean difference, and a comparison between different groups was conducted using an independent sample $t$ test or Mann-Whitney $U$ test. For testing the marginal homogeneity between tobacco use before and after residing in Saudi Arabia, the McNemar test was used, and the results presented as text.

All analyses were performed using SAS/STAT version 9.2 (SAS Institute Inc., Cary, NC, USA). A 2-sided P value $<0.05$ was considered statistically significant. To compare changes in lifestyle behaviour, a 5-year cutoff point was used as it reflected the median length of residence in Saudi Arabia.

\section{Ethical standards}

This study was conducted according to the principles expressed in the Declaration of Helsinki. Furthermore, it was reviewed and approved by the Institutional Review Board of KSU, College of Medicine; approval letter number is $13-372$. In addition, written informed consent was obtained from each participant prior to participation in the study.

\section{Results}

\section{Sociodemographic characteristics of the studied population}

There were 1437 expatriates in our study; 1091 (75.9\%) were non-Saudi Arabs, 37 (2.57\%) were from different nationalities, and 309 (21.5\%) were South Asians. The mean age of participants was 40.9 (SD 11.7) years, and more details about sociodemographic characteristics are shown in Table 1.

\section{Prevalence of BCVRFs}

One hundred and fifty-six (11\%) of the participants were current tobacco users; 1049 (73\%) were physically inactive; and women were more physically inactive than men were (Table 1). Moreover, 1264 (88\%) of the participants were reported to have low intake of fruit and vegetables and women had a significantly higher rate of low fruit and vegetable consumption compared to men $(P<001)$. Three hundred and seventy-eight (26\%) of the expatriates had MetS, but not statistically significant difference was observed between genders $(P=0.08)$.

\section{Effect of living in Saudi Arabia on BCVRFs}

\section{Tobacco use}

There was a low rate of current daily tobacco use $(\mathrm{n}=156 ; 11 \%)$. The prevalence before and after residing in Saudi Arabia (using McNemar test) was $16 \%(n=134)$ and $15.4 \%(n=$ 129) for men and $2.8 \%(n=17)$ and $3.1 \%(n=18)$ for women, respectively. Although this indicates that living in Saudi Arabia had a small effect on the pattern of tobacco use (higher in men and lower in women), the changes were not statistically significant.

\section{Dietary intake}

Table 2 presents the mean and SD of number of days of eating fruit and vegetables, as well as the number of servings per day before and after residing in Saudi Arabia. There were significant differences in both measures before and after coming to live in Saudi Arabia $(P<$ 0.001 for both comparisons). However, these differences, particularly reduced fruit consumption, were significantly higher among women and individuals who had resided $>5$ years in Saudi Arabia compared to their counterparts $(P<0.001$ and $P=0.001$, respectively $)$ (Table 3). In contrast, the consumption offastfoodincreased significantlyalmost threefold during living in Saudi Arabia $(P<0.001)$ (Table 2). This increased consumption was significantly higher among men than women $(P<0.001)$, and among newcomers $(<5$ years residence) compared to those with longer length of stay $(P<0.001)$ (Table 3).

\section{Physical activity}

Physical activity patterns in all domains, such as travel to work, traveling to/ from places or recreational activities were affected negatively by living in Saudi Arabia. Thus, the number of days and duration of physical activity were decreased noticeably during residence in Saudi Arabia (Table 2). This decrease was significantly higher in the first 5 


\begin{tabular}{|c|c|c|c|c|}
\hline Sociodemographic characteristics & Total & $\begin{array}{c}\text { Men } \\
n(\%) \\
840(58 \%)\end{array}$ & $\begin{array}{c}\text { Women } \\
n(\%) \\
597(42 \%)\end{array}$ & $P$ \\
\hline $\operatorname{Age}(y r) ;$ mean $(S D)$ & $40.9(11.7)$ & $41.9(11.7)$ & $39.1(11.5)$ & $<0.001$ \\
\hline \multicolumn{5}{|l|}{ Educational level; n (\%) } \\
\hline Higher education (college and above) & $1265(88)$ & 798(63) & $467(37)$ & $<0.001$ \\
\hline Essential education $^{a}$ & $168(12)$ & $42(25)$ & $126(75)$ & $<0.001$ \\
\hline Illiterate & $4(0.3)$ & 0 & $4(100)$ & 0.005 \\
\hline \multicolumn{5}{|l|}{ Participant status in KSU; $n$ (\%) } \\
\hline Employee & $969(67)$ & $773(80)$ & $196(20)$ & $<0.001$ \\
\hline Family member & $468(33)$ & $67(14)$ & $401(86)$ & $<0.001$ \\
\hline \multicolumn{5}{|l|}{ Occupation; n (\%) } \\
\hline Faculty staff & $555(37)$ & $452(81)$ & $103(19)$ & $<0.001$ \\
\hline Healthcare provider & $96(7)$ & $39(41)$ & $57(59)$ & $<0.001$ \\
\hline Technician & $16(1)$ & $14(88)$ & $2(13)$ & $<0.001$ \\
\hline Administrative & $24(2)$ & $14(58)$ & $10(42)$ & $<0.001$ \\
\hline Other KSU employee & $278(19)$ & $254(91)$ & $24(9)$ & $<0.001$ \\
\hline \multicolumn{5}{|l|}{ Marital status; $n$ (\%) } \\
\hline Single & $106(7)$ & $54(51)$ & $52(49)$ & 0.01 \\
\hline Married & 1321(92) & $784(59)$ & $537(41)$ & 0.01 \\
\hline Widowed / divorced & $10(1)$ & $2(20)$ & $8(80)$ & 0.01 \\
\hline \multicolumn{5}{|l|}{ Behavioural risk factors; $n$ (\%) } \\
\hline Tobacco use & $156(11)$ & $134(16)$ & $22(3)$ & $<0.001$ \\
\hline Physical inactivity & $1049(73)$ & $539(64)$ & $510(84)$ & $<0.001$ \\
\hline Low fruit/vegetable intake & $1264(88)$ & $731(87)$ & $533(89)$ & 0.11 \\
\hline \multicolumn{5}{|c|}{ MetS according to NCEP-ATP III criteria; n (\%) } \\
\hline Total & $378(26)$ & $233(28)$ & $145(24)$ & 0.08 \\
\hline
\end{tabular}

${ }^{a}$ Essential education indicated completion of any school: elementary, preparatory or high school. KSU = King Saud University; MetS = metabolic syndrome; NCEP-ATP III = National Cholesterol Education Program Expert Panel on Detection, Evaluation, and Treatment of High Blood Cholesterol in Adults (Adult Treatment Panel III); SD = standard deviation.

years of living in Saudi Arabia than in later years for both domains of physical activity (work and sport), whereas not statistically significant changes were reported between the lengths of stay and type of traveling (Table 4). A significant reduction in physical activity in both work and recreational domains was higher in men than in women.

\section{Association between food consumption and MetS}

The intake of fruit and vegetables remained low in both groups, with or without MetS, and there was no association between MetS and low intake of fruit and vegetables. However, consumption of fast food was significantly lower among people with MetS $(P=0.001)$ (Table 3$)$. Furthermore, MetS was not associated with physical activity pattern changes in all domains.

\section{Discussion}

Our findings indicate that non-Saudi participants demonstrated significant negative effects on BCVRFs after their arrival in Saudi Arabia; namely, high rate of physical inactivity, high consumption of fast food and low consumption of fruit and vegetables.

The expatriates' low consumption of fruit and vegetables is comparable with the Saudi participants in the larger study (14), as well as country-wide population findings (18), and agrees with other studies worldwide (19).

Also noteworthy, in recent decades, GCC nations have been influenced by a global trend towards high consumption of fast food, which is thought to have the following attributes: fast food is often quick, delicious, appealing to all age groups and affordable to all socioeconomic classes (20). Moreover, within Saudi Arabia, fast food is generally available and easily accessible throughout the year through a wide variety of global fast food chains, especially in food courts of modern shopping malls (21). This could also 


\begin{tabular}{|c|c|c|c|c|}
\hline Question & $\begin{array}{l}\text { Before living in } \\
\text { Saudi Arabia }\end{array}$ & $\begin{array}{l}\text { After living in } \\
\text { Saudi Arabia }\end{array}$ & $\begin{array}{l}\text { Mean } \\
\text { difference }\end{array}$ & $\boldsymbol{P}$ \\
\hline \multicolumn{5}{|l|}{ Dietary pattern, mean (SD) } \\
\hline In a typical week, on how many days do you eat fruit? & $4.59(2.14)$ & $4.81(2.06)$ & 0.22 & $<0.001^{*}$ \\
\hline How many servings of fruit do you eat a day? & $1.95(1.18)$ & $1.92(1.13)$ & 0.03 & $<0.001^{*}$ \\
\hline In a typical week, on how many days do you eat vegetables? & $5.17(1.96)$ & $5.10(1.98)$ & 0.07 & $<0.001^{*}$ \\
\hline How many servings of vegetables do you eat a day? & $2.34(1.35)$ & $2.32(1.32)$ & 0.02 & $<0.001^{*}$ \\
\hline $\begin{array}{l}\text { How many fast food meals per week do you eat that were not } \\
\text { prepared at home? }\end{array}$ & $1.27(2.35)$ & $3.42(5.40)$ & -2.14 & $<0.001^{*}$ \\
\hline \multicolumn{5}{|l|}{$\begin{array}{l}\text { Physical activities } \\
\text { Work }\end{array}$} \\
\hline $\begin{array}{l}\text { In a typical week, how many days do you do vigorous-intensity } \\
\text { activities as part of your work? }\end{array}$ & $0.50(1.45)$ & $0.30(1.05)$ & 0.20 & $<0.001^{*}$ \\
\hline $\begin{array}{l}\text { How much time do you spend doing vigorous-intensity activities at } \\
\text { work on a typical day? (min) }\end{array}$ & $18.27(57.07)$ & $11.16(42.10)$ & 7.37 & $<0.001^{*}$ \\
\hline $\begin{array}{l}\text { In a typical week, how many days do you do moderate-intensity } \\
\text { activities as part of your work? }\end{array}$ & $3.50(2.82)$ & $3.03(2.62)$ & 0.47 & $<0.001^{*}$ \\
\hline $\begin{array}{l}\text { How much time do you spend doing moderate-intensity activities } \\
\text { at work on a typical day? (min) }\end{array}$ & $75.49(87.69)$ & $54.36(70.61)$ & 21.13 & $<0.001$ \\
\hline \multicolumn{5}{|l|}{ Travel to and from places } \\
\hline $\begin{array}{l}\text { In a typical week, on how many days do you do walk or cycle for } \geq \\
10 \text { min continuously to get to/from places? }\end{array}$ & $5.08(2.72)$ & $3.51(2.92)$ & 1.57 & $<0.001^{*}$ \\
\hline $\begin{array}{l}\text { How much time do you spend walking or cycling for travel on a } \\
\text { typical day? (min) }\end{array}$ & $78.28(74.87)$ & $36.95(43.78)$ & 44.33 & $<0.001^{*}$ \\
\hline \multicolumn{5}{|l|}{ Recreational activities } \\
\hline $\begin{array}{l}\text { In a typical week, on how many days do you do vigorous-intensity } \\
\text { sports, fitness or recreational (leisure) activities? }\end{array}$ & $0.83(1.68)$ & $0.57(1.38)$ & 0.26 & $<0.001$ \\
\hline $\begin{array}{l}\text { How much time do you spend doing vigorous-intensity sports, } \\
\text { fitness or recreational activities on a typical day? (min) }\end{array}$ & $23.04(52.18)$ & 13.59 (33.68) & 9.11 & $<0.001$ \\
\hline $\begin{array}{l}\text { In a typical week, on how many days do you do moderate-intensity } \\
\text { sports, fitness or recreational activities? }\end{array}$ & $2.07(2.59)$ & $1.53(2.18)$ & 0.54 & $<0.001^{*}$ \\
\hline $\begin{array}{l}\text { How much time do you spend doing moderate-intensity sports, } \\
\text { fitness or recreational activities on a typical day? (min) }\end{array}$ & $33.94(50.15)$ & $21.92(33.85)$ & 12.021 & $<0.001^{*}$ \\
\hline
\end{tabular}

*Tests were done using Mann-Whitney $U$ test. $S D=$ standard deviation.

explain our reported significant increase in fast food intake by expatriates during their residence in Saudi Arabia, which resembles that in the larger study (14) and the findings of prior Saudi and GCC studies $(22,23)$. Moreover, previous studies have indicated that men consume more fast food than women do $(24,25)$, which is in accordance with the findings of our study. One reason for this could be the greater number of social activities for men (26).

Substantial evidence worldwide supports the results of the present study concerning the changes in dietary pattern among expatriates living in Saudi Arabia. This transition in nutritional habits and consumption is usually associated with dietary acculturation when the migrants adopt the dietary practices of the host country $(11,12,27)$.

Saudi Arabia, like other GCC countries, has witnessed vast change in wealth and subsequent urbanization over the past few decades. This led to a sedentary lifestyle, in part due to increased use of motorized commuting, as well as changes to the nature of the work environment and facilities that require less physical activity (28). A significant decline was observed in the physical activity of expatriate employees and their families in this study during their residence in Saudi Arabia. Such changes were more marked during the first 5 years of residence. Moreover, these results are in line with findings from other Saudi and regional studies $(18,28,29)$.

The significant changes in physical activity levels were reported by male participants, which indicates that expatriate men were more physically active than women in their homeland (30). Nevertheless, overall women from the larger study (14) as well as expatriate 


\begin{tabular}{|c|c|c|c|}
\hline \multicolumn{4}{|l|}{ Length of stay in Saudi Arabia } \\
\hline Covariate & $<5 \mathrm{yr}, \mathrm{n}=634$ & $\geq 5 \mathrm{yr}, \mathrm{n}=\mathbf{8 0 3}$ & $\boldsymbol{P}$ \\
\hline \multicolumn{4}{|l|}{ Fruit/vegetable intake, mean (SD) } \\
\hline Number of days eating fruit & $0.39(1.79)$ & $0.09(1.74)$ & $0.001^{*}$ \\
\hline Number of fruit servings/day change & $0.08(0.88)$ & $-0.11(0.95)$ & $<0.001$ \\
\hline Number of days of ate Vegetables change & $-0.05(1.54)$ & $-0.09(1.29)$ & $0.639^{*}$ \\
\hline Number of Vegetable servings change & $-0.03(0.93)$ & $-0.02(0.82)$ & $0.345^{*}$ \\
\hline Fast food change & $3.26(6.66)$ & $1.27(3.84)$ & $<0.001$ \\
\hline Gender & Male, $n=840$ & Female, $n=597$ & $P$ \\
\hline Number of days eating fruit & $0.43(1.92)$ & $-0.07(1.48)$ & $<0.001^{*}$ \\
\hline Number of fruit servings/day change & $0.06(0.93)$ & $-0.14(0.91)$ & $<0.001^{*}$ \\
\hline Number of days of ate Vegetables change & $-0.06(1.59)$ & $-0.09(1.11)$ & 0.698 \\
\hline Number of Vegetable servings change & $-0.02(0.85)$ & $-0.04(0.89)$ & $0.334^{*}$ \\
\hline Fast food change & $3.32(6.52)$ & $0.49(2.2)$ & $<0.001^{*}$ \\
\hline MetS NCEP_ATPIII criteria & Normal, $\mathrm{n}=1059$ & MetS, $\mathrm{n}=378$ & $P$ \\
\hline Number of days eating fruit & $0.23(1.84)$ & $0.22(1.56)$ & 0.933 \\
\hline Number of fruit servings/day change & $0.0(0.93)$ & $-0.09(0.9)$ & $0.097^{*}$ \\
\hline Number of days of ate Vegetables change & $-0.07(1.47)$ & $-0.09(1.22)$ & $0.886^{*}$ \\
\hline Number of Vegetable servings change & $-0.01(0.87)$ & $-0.08(0.88)$ & $0.369^{*}$ \\
\hline Fast food change & $2.42(5.63)$ & $1.36(4.43)$ & 0.001 \\
\hline
\end{tabular}

*Tests performed by Mann-Whitney U test. MetS = metabolic syndrome; NCEP-ATP III = National Cholesterol Education Program Expert Panel on Detection, Evaluation, and Treatment of High Blood Cholesterol in Adults (Adult Treatment Panel III); SD = standard deviation.

women in this study all reported higher rates of physical inactivity compared to men, and this finding is strongly consistent with previous reports from Saudi Arabia and the region $(18,28$, 29). Reasons behind this phenomenon among women could be due to the prevailing conservative social norms and restrictions on outdoor exercise for women in Saudi Arabia. Another possible contributing factor to such high rates of physical inactivity among all participants after living in Saudi Arabia is the hot arid climate in the Gulf Region, which is present for a substantial part of the year and restricts outdoor activities (31). In addition, Saudi Arabia has a scarcity of sidewalks, parks and facilities, which is not conducive for walking and sporting activities (32).

We observed that there was no association between the negative changes in physical activity pattern or consumption of fruit and vegetables and MetS status. However, there was an inverse correlation between fast food intake and MetS status. The only explanation is that participants with MetS were more aware of the negative effects of fast food on their health, hence participants with MetS reported less consumption (33).

This study is one of the few to explore the possible effects of living in Saudi Arabia on BCVRFs of expatriate employees and their families. It represents a comprehensive survey of BCVRFs using a standardized WHO STEPwise approach; furthermore, data were collected by well-trained research assistants under close supervision.

Nevertheless, the limitations of this study include the following. First, the answers to questions about behavioural risk factors, such as dietary habits, physical inactivity and tobacco use were self-reported. In addition, relying on memories about past behaviour could have led to over- or under-reporting. Second, the results cannot be generalized to the entire expatriate population in Saudi Arabia as the sample was not randomly selected. Finally, due to its cross-sectional design, the study does not allow us to assess whether MetS was prevalent or not before entering Saudi Arabia.

Despite the above limitations, this was a comprehensive survey and the findings are expected to inform public health policy and practice, to take further steps towards best interventions for changing adverse behavioural patterns in $\mathrm{KSU}$, including among the expatriate population.

\section{Conclusions and recommendations}

Our study indicated a high prevalence of BCVRFs among the study population. Non-Saudi participants showed a higher rate of physical inactivity, higher consumption of fast food and lower 


\begin{tabular}{|c|c|c|c|}
\hline Covariate & $0-5 y r, n=634$ & $\geq 5 \mathrm{yr}, \mathbf{n}=\mathbf{8 0 3}$ & $\boldsymbol{P}$ \\
\hline \multicolumn{4}{|l|}{ Work } \\
\hline Number of days of vigorous activity change & $-0.28(1.11)$ & $-0.14(1.04)$ & $<0.001^{*}$ \\
\hline Time consumed in vigorous change (in minutes) & $-9.32(46.54)$ & $-5.85(39.7)$ & $0.012^{*}$ \\
\hline Number of days of moderate activity change & $-0.67(1.77)$ & $-0.31(1.65)$ & $<0.001^{*}$ \\
\hline Time consumed in moderate change ( in minutes) & $-25.66(60.2)$ & $-16.92(65.0)$ & $0.001^{*}$ \\
\hline \multicolumn{4}{|l|}{ Travel to and from places } \\
\hline Number of days of Walk change & $-1.64(2.78)$ & $-1.55(2.74)$ & $0.573^{*}$ \\
\hline Time consumed in Walk change ( in minutes) & $-41.5(65.95)$ & $-41.94(70.81)$ & 0.246 \\
\hline \multicolumn{4}{|l|}{ Recreational activities } \\
\hline Number of days of sport vigorous change & $-0.3(1.53)$ & $-0.23(1.44)$ & 0.248 \\
\hline Time consumed in of sport vigorous change (in minutes) & $-10.74(44.76)$ & $-7.84(48.14)$ & $0.337^{*}$ \\
\hline Number of days of sport moderate change & $-0.62(2.34)$ & $-0.48(2.18)$ & 0.248 \\
\hline \multirow[t]{2}{*}{ Time consumed in sport moderate change (in minutes) } & $-13.07(43.07)$ & $-10.83(43.95)$ & 0.337 \\
\hline & Male, $\mathrm{n}=840$ & Female, $\mathrm{n}=597$ & $P$ \\
\hline \multicolumn{4}{|l|}{ Work } \\
\hline Number of days of vigorous activity change & $-0.25(1.18)$ & $-0.14(0.9)$ & $<0.001^{*}$ \\
\hline Time consumed in vigorous change(in minutes) & $-8.96(43.83)$ & $-5.1(41.37)$ & $0.001^{*}$ \\
\hline Number of days of moderate activity change & $-0.57(1.69)$ & $-0.32(1.73)$ & $0.001^{*}$ \\
\hline Time consumed in moderate change (in minutes) & $-22.57(58.95)$ & $-18.25(8.44)$ & 0.203 \\
\hline \multicolumn{4}{|l|}{ Travel to and from places } \\
\hline Number of days of Walk change & $-0.77(2.12)$ & $-2.75(3.12)$ & $<0.001^{*}$ \\
\hline Time consumed in Walk change (in minutes) & $-43.42(61.83)$ & $-39.42(77.26)$ & $0.05^{*}$ \\
\hline \multicolumn{4}{|l|}{ Recreational activities } \\
\hline Number of days of sport vigorous change & $-0.29(1.55)$ & $-0.23(1.39)$ & $0.34^{*}$ \\
\hline Time consumed in of sport vigorous change (in minutes) & $-12.39(56.25)$ & $-4.51(27.68)$ & 0.011 \\
\hline Number of days of sport moderate change & $-0.52(2.25)$ & $-0.57(2.25)$ & $0.689 *$ \\
\hline Time consumed in sport moderate change (in minutes) & $-10.93(43.01)$ & $-13.07(44.35)$ & $0.703^{*}$ \\
\hline
\end{tabular}

Values are presented as mean (standard deviation). *Tested by Mann-Whitney $U$ test

consumption of fruit and vegetables after their arrival in Saudi Arabia. Living in Saudi Arabia had a different impact on gender. Among women a significant reduction was reported in physical activity and intake of fruit and vegetables, while men reported greater fast food consumption. There was no association between the changes in physical activity or intake of fruit and vegetables and MetS, except that the intake of fast food was lower among participants with MetS.

Based on the findings ofourstudy, we recommend building an effective public health strategy to prevent cardiovascular events, and to improve cardiovascular wellness among the university staff and their dependents. This should be done through the following. (1)A behavioural intervention programme focusing on promoting and sustaining a healthy diet and active lifestyle at the university level could prevent and reduce the burden of diet-related diseases. (2) Such a high rate of behavioural risk factors is enough to justify both population- and highrisk-based public health intervention programmes and health promotion activities to prevent further increases, and to manage future cardiovascular disease burden at both university and national levels.

\section{Acknowledgements}

We would like to thank all heads of concerned departments for their support and approval and to the research assistants for their help with data collection. Special thanks are directed to the participants of the study, without whom, this work would not have been possible. The funder had no role in study design, data collection, data analysis, decision or writing up of the manuscript.

Funding: King Abdulaziz City for Science and Technology (KACST), research grant number MS 34-5.

Competing interests: None declared. 


\section{References}

1. Gulf Cooperation Council: international organization. Encyclopaedia Britannica (http://global.britannica.com/topic/ Gulf-Cooperation-Council, accessed 18 January 2018.

2. Khawjakiah $\mathrm{MH}$, Hisham E. Future of industrialization and technology in the light of the Gulf and Egyptian experiences. Kuwait: Arab Institute of Planning; 1989.

3. Ministry of Health, Kingdom of KSA. Statistical year book (http://www.moh.gov.sa/en/Ministry/Statistics/book/Documents/Statistical-Book-for-the-Year-1435.pdf, accessed 18 January 2018).

4. Saudi Arabia - visas, residency, immigration \& documentation (http://www.expatfocus.com/expatriate-saudi-arabiaresidency, accessed 18 January 2018).

5. Lassetter JH, Callister LC. The impact of migration on the health ofvoluntary migrants in western societies. JTranscult Nurs. 2009 Jan;20(1):93-104. https://doi.org/10.1177/1043659608325841 PMID:18840884

6. Physical activity. Fact sheet updated February 2017 (http:// www.who.int/mediacentre/factsheets/fs385/en/, accessed 18 January 2018).

7. Musaiger AO. Overweight and obesity in eastern mediterranean region: prevalence and possible causes. J Obes. 2011;2011:407237. https://doi.org/10.1155/2011/407237 PMID:21941635

8. Global health risks. Mortality and burden of disease attributable to selected major risks. Geneva: World Health Organization (http://apps.who.int/iris/bitstre am/10665/44203/1/9789241563871_eng.pdf?ua=1, accessed 18 January 2018).

9. Hall JN, Moore S, Harper SB, Lynch JW. Global variability in fruit and vegetable consumption. Am J Prev Med. 2009 May;36(5):402-409.e5. https://doi.org/10.1016/j.amepre.2009.01.029 PMID:19362694

10. El Bcheraoui C, Basulaiman M, AIMazroa MA, Tuffaha M, Daoud F, Wilson N, et al. Fruit and vegetable consumption among adults in KSA, 2013. Nutr Diet Suppl. 2015 Feb 20;7:419. https://doi.org/10.2147/NDS.S77460

11. Berry JW. Immigration, acculturation and adaptation. Appl Psychol. 1997;46(1):63.

12. Satia-Abouta J, Patterson RE, Neuhouser ML, Elder J. Dietary acculturation: applications to nutrition research and dietetics. J Am Diet Assoc. 2002 Aug;102(8):1105-18. https://doi. org/10.1016/S0002-8223(02)90247-6 PMID:12171455

13. Pérez-Escamilla R, Putnik $P$. The role of acculturation in nutrition, lifestyle, and incidence of type 2 diabetes among Latinos. J Nutr. 2007 Apr;137(4):860-70. https://doi.org/10.1093/ jn/137.4.860 PMID:17374645

14. Alzeidan R, Rabiee F, Mandil A, Hersi A, Fayed A. Non-communicable disease risk factors among employees and their families of a Saudi University: an epidemiological study. PLoS One. 201611 4;11(11):e0165036. https://doi.org/10.1371/journal.pone.0165036 PMID:27814369

15. WHO STEPS instrument (core and expanded). World Health Organization (http://www.who.int/ncds/surveillance/steps/ STEPS_Instrument.pdf, accessed 18 January 2018).

16. National Cholesterol Education Program (NCEP) Expert Panel on Detection, Evaluation, and Treatment of High Blood Cholesterol in Adults (Adult Treatment Panel III). Third Report of the National Cholesterol Education Program (NCEP) Expert Panel on Detection, Evaluation, and Treatment of High Blood Cholesterol in Adults (Adult Treatment Panel III) final report. Circulation. 2002 Dec 17;106(25):3143-421. PMID:12485966
17. Grundy SM, Cleeman JI, Merz CN, Brewer HB Jr, Clark LT, Hunninghake DB, et al.; National Heart, Lung, and Blood Institute; American College of Cardiology Foundation; American Heart Association. Implications of recent clinical trials for the National Cholesterol Education Program Adult Treatment Panel III guidelines. Circulation. 2004 Jul 13;110(2):227-39. https:// doi.org/10.1161/01.CIR.0000133317.49796.0E PMID:15249516

18. Amin TT, Al Sultan Al, Mostafa OA, Darwish AA, Al-Naboli MR. Profile of non-communicable disease risk factors among employees at a Saudi university. Asian Pac J Cancer Prev. 2014;15(18):7897-907. https://doi.org/10.7314/APJCP.2014.15.18.7897 PMID:25292084

19. Goulão B, Santos $O$, Carmo I. The impact of migration on body weight: a review. Cad Saude Publica. 2015 Feb;31(2):229-45. https://doi.org/10.1590/0102-311X00211913 PMID:25760158

20. DeMaria AN. Of fast food and franchises. J Am Coll Cardiol. 2003 Apr 2;41(7):1227-8. https://doi.org/10.1016/S07351097(03)00294-8 PMID:12679226

21. Mahfouz AA, Abdelmoneim I, Khan MY, Daffalla AA, Diab $\mathrm{MM}, \mathrm{Al}-\mathrm{Gelban} \mathrm{KS}$, et al. Obesity and related behaviors among adolescent school boys in Abha City, Southwestern KSA. J Trop Pediatr. 2008 Apr;54(2):120-4. https://doi.org/10.1093/ tropej/fmm089 PMID:18039676

22. ALFaris NA, Al-Tamimi JZ, Al-Jobair MO, Al-Shwaiyat NM. Trends of fast food consumption among adolescent and young adult Saudi girls living in Riyadh. Food Nutr Res. 2015 03 18;59(1):26488. https://doi.org/10.3402/fnr.v59.26488 PMID:25792229

23. bin Zaal AA, Musaiger AO, D'Souza R. Dietary habits associated with obesity among adolescents in Dubai, United Arab Emirates. Nutr Hosp. 2009 Jul-Aug;24(4):437-44. PMID:19721923

24. Moore LV, Diez Roux AV, Nettleton JA, Jacobs DR, Franco M. Fast-food consumption, diet quality, and neighborhood exposure to fast food: the multi-ethnic study of atherosclerosis. Am J Epidemiol. 2009 Jul 1;170(1):29-36. https://doi.org/10.1093/ aje/kwp090 PMID:19429879

25. Anderson B, Rafferty AP, Lyon-Callo S, Fussman C, Imes G. Fastfood consumption and obesity among Michigan adults. Prev Chronic Dis. 2011 Jul;8(4):A71. PMID:21672395

26. Maccoby EE. Gender and relationships. A developmental account. Am Psychol. 1990 Apr;45(4):513-20. https://doi. org/10.1037/0003-066X.45.4.513 PMID:2186679

27. Nakamura Y, Ueshima H, Okuda N, Miura K, Kita Y, Okamura T, et al.; INTERLIPID Research Group. Relation of dietary and lifestyle traits to difference in serum leptin of Japanese in Japan and Hawaii: the INTERLIPID study. Nutr Metab Cardiovasc Dis. 2012 Jan;22(1):14-22. https://doi.org/10.1016/j.numecd.2010.03.004 PMID:20678905

28. Mabry RM, Reeves MM, Eakin EG, Owen N. Evidence of physical activity participation among men and women in the countries of the Gulf cooperation council: a review. Obes Rev. 2010 Jun;11(6):457-64. https://doi.org/10.1111/j.1467789X.2009.00655.x PMID:19793376

29. Al-Zalabani AH, Al-hamdan NA, Saeed AA. The prevalence of physical activity and its socioeconomic correlates in Kingdom of KSA: a cross-sectional population-based national survey. J Taibah Univ Med Sci. 2015;10(2):208-15. https://doi. org/10.1016/j.jtumed.2014.11.001

30. Pengpid S, Peltzer K, Kassean HK, Tsala Tsala JP, Sychareun V, Müller-Riemenschneider F. Physical inactivity and associated factors among university students in 23 low-, middle- and high-income countries. Int J Public Health. 2015 
Jul;60(5):539-49. https://doi.org/10.1007/s00038-015-06800 PMID:25926342

31. Serour M, Alqhenaei $\mathrm{H}, \mathrm{Al}-\mathrm{Saqabi} \mathrm{S}$, Mustafa AR, Ben-Nakhi A Cultural factors and patients' adherence to lifestyle measures. Br J Gen Pract. 2007 Apr;57(537):291-5. PMID:17394732

32. Al-Nakeeb $\mathrm{Y}$, Lyons $\mathrm{M}$, Collins $\mathrm{P}$, Al-Nuaim A, Al-Hazzaa $\mathrm{H}$, Duncan MJ, et al. Obesity, physical activity and sedentary behavior amongst British and Saudi youth: a cross-cultural study. Int J Environ Res Public Health. 2012 Apr;9(4):1490-506. https://doi.org/10.3390/ijerph9041490 PMID:22690207

33. Hosseinpour-Niazi S, Mirmiran P, Mirzaei S, Azizi F. Cereal, fruit and vegetable fibre intake and the risk of the metabolic syndrome: a prospective study in the Tehran Lipid and Glucose Study. J Hum Nutr Diet. 2015 Jun;28(3):236-45. https://doi. org/10.1111/jhn.12242 PMID:24890325 